\title{
STRATEGI PENGEMBANGAN BADAN USAHA MILIK DESA (BUMDES) UNIT USAHA TERNAK SAPI POTONG BERDASARKAN MODAL SOSIAL PETERNAK DI KABUPATEN TANJUNG JABUNG TIMUR
}

\section{DEVELOPMENT STRATEGY OF VILLAGE - OWNED BUSINESS AGENCIES (BUMDES) BASED ON LIVESTOCK SOCIAL CAPITAL IN TANJUNG JABUNG EAST REGENCY}

Taufiq Arrahman ", Firmansyah, Bayu Rosadi, Afriani Harahap, Syafril Hadi dan Farizal Magister Ilmu Peternakan Program Pascasarjana Universitas Jambi

*Penulis koresponden, email : taufikarrahma05@gmail.com

\begin{abstract}
ABSTRAK
Penelitian ini bertujuan untuk menganalisis pengaruh modal sosial peternak terhadap pengembangan badan Usaha Milik Desa (BUMDes) unit usaha ternak sapi di Kabupaten Tanjung Jabung Timur dan menyusun serangkaian strategi pengembangan BUMDes unit usaha ternak sapi berdasarkan modal sosial peternak di Kabupaten Tanjung Jabung Timur.Metode penelitian yang digunakan pada penelitian ini adalah metode survey,dengan teknik penarikan sampel pada penelitian ini ialah Cluster Random Sampling. Selain itu untuk ukuran sampel dalam penelitian ini ditentukan dengan menggunakan metoda iterati. Metodeanalisis yang digunakan analisis adalahRegresi Berganda StepWise, analisis SWOT dan analisis QSPM. Berdasarkan hasil penelitian dapat disimpulkan bahwa pengembangan BUMDes unit usaha ternak sapi di Kabupaten Tanjung Jabung Timur dipengaruhi oleh modal sosial berupa kepercayaan dan jaringan sosial.Strategi pengembangan BUMDes unit usaha ternak sapi di Kabupaten Tanjung Jabung Timur adalah penguatan kapasitas modal sosial dengan peningkatan kepercayaan masyarakat pengelolaan BUMDes yang transparan, akuntabel, dan berlandaskan nilai-nilai kejujuran.
\end{abstract}

Kata Kunci: Strategi Pengembangan; Badan Usaha Milik Desa (BUMDes); dan Modal Sosial

\section{ABSTRACT}

This study aims to analyze the effect of farmer's social capital on the development of Village Owned Enterprises (BUMDes) cattle business units in East TanjungJabung Regency and develop a series of strategies for developing BUMDes cattle business units based on farmer's social capital in East TanjungJabung Regency. The research method used in this study is a survey method, with the sampling technique used in this study is Cluster Random Sampling. In addition, the sample size in this study was determined using the iterative method. The analytical method used in the analysis is StepWise Multiple Regression, SWOT analysis and QSPM analysis. Based on the results of the study, it can be concluded that the development of BUMDes cattle business units in TanjungJabungTimur Regency is influenced by social capital in the form of trust and social networks. The strategy for developing the BUMDes cattle business unit in TanjungJabungTimur Regency is to strengthen the capacity of social capital by increasing public trust in the management of BUMDes that is transparent, accountable, and based on the values of honesty.

Keywords: Development Strategy; Village Owned Enterprises (BUMDes); and Social Capital

\section{PENDAHULUAN}

Kondisi peternakan sapi saat ini masih mengalami kekurangan pasokan sapi bakalan local karena pertambahan populasi tidak seimbang dengan kebutuhan nasional, sehingga terjadi impor sapi potong bakalan 
dan daging. Kebutuhan daging sapi di Indonesia saat ini dipasok dari tiga pemasok yaitu peternak rakyat (ternak lokal), industry peternakan rakyat (hasil penggemukan sapi ex-import) dan impor daging. Selanjutnya dijelaskan bahwa untuk tetap menjaga keseimbangan antara penawaran dan permintaan ternak potong, usaha peternakan rakyat tetap menjadi tumpuan utama, namun tetap menjaga kelestarian sumberdaya ternak sehingga setiap tahun mendapat tambahan akhir positif (Arbi et al., 2016).

Lembaga perekonomian desa atau disebut BUMDes (Badan Usaha Milik Desa) yang menjadi pendekatan baru dalam upaya pemerintah mewujudkan kesejahteraan masyarakat desa melalui kemandirian masyarakat desa itu sendiri. BUMDes sebagai pilar baru kegiatan ekonomi di desa berfungsi sebagai lembaga sosial (social institution) dan komersial (commercial institution). Konsep lembaga sosial dapat dijelaskan bahwa seluruh hasil akhir kegiatan BUMDes ditunjukan pada kepentingan masyarakat melalui kontribusinya dalam penyediaan berbagai kebutuhan dan pelayanan sosial. Sedangkan konsep lembaga komersial lebih ditujukan untuk orientasi keuntungan (profit oriented) melalui mekanisme pengelolaan potensi desa sebagai komoditas yang bisa diperjualbelikan sebagai pemasukan bagi desa. Kedua konsep ini berpengaruh pada proses pengelolaan usaha sehingga perlu menekankan efisiensi dan efektifitas demi tercapainya tujuan BUMDes sebagai lembaga ekonomi desa yang mengelola potensi desa untuk kesejahteraan desa melalui kegiatan usahanya (Departemen Pendidikan Nasional 2007).

Pendekatan semacam ini setidaknya menjelaskan bahwa BUMDes merupakan instrumen modal sosial (social capital) yang dimiliki desa untuk mencapai proses kesejahteraan sekaligus pemberdayaan. Modal sosial dijelaskan sebagai hubungan dengan serangkaian jaringan yang memiliki kesamaan nilai dan diwujudkan dalam bentuk kerjasama untuk capai tujuan yang diinginkan bersama. Modal sosial yang diidentikan dengan hubungan jaringan mengharuskan BUMDes memiliki relasi dengan beberapa elemen yang ada di desa maupun luar desa baik lembaga atau organisasi dan individu atau masyarakat yang memiliki kesamaan nilai untuk mewujudkan tujuannya. Untuk itu, harus diakui bahwa peran dari modal sosial sangat penting dalam mencapai tujuan masyarakat desa yang sejahtera melalui BUMDes.

Berdasarkan Laporan Kementerian Desa, Pembangunan Daerah Tertinggal dan Transmigrasi (2018), Kabupaten Tanjung Jabung Timur memiliki 69 BUMDes yang tersebar di 10 kecamatan, tetapi hanya terdapat 4 BUMDes di Kabupaten Tanjung Jabung Timur unit usahanya bergerak di bidang peternakan yaitu BUMDes berasal dari Desa Pandan Sejahtera, Desa Pandan Makmur, Desa Mencolok dan Desa Rawasari.

Untuk mengembangkan BUMDes dengan unit usaha ternak sapi Kabupaten Tanjung Jabung Timur dibutuhkan modal sosial yang erat dan kuat untuk keberlangsungan lembaga ini. Menurut Carpenter (2004), modal sosial merupakan kemampuan yang muncul dari kelaziman kepercayaan dalam suatu masyarakat atau dalam bagian tertentu dari masyarakat. Masyarakat yang saling percaya akan lebih baik dalam inovasi organisasi karena kepercayaan yang tinggi memungkinkan munculnya rentang hubungan sosial yang lebar. Menurut Putra (2008) juga mendifinisikan bahwa modal sosial adalah hubungan yang terjadi dan diikat oleh suatu kepercayaan (trust), saling pengertian (mutual understanding), dan nilai-nilai bersama (shared value) yang mengikat anggota kelompok untuk membuat kemungkinan aksi bersama secara efisien dan efektif, modal sosial terdiri dari unsur kepercayaan, jaringan sosial, hubungan timbal balik dan norma bertujuan untuk perluasan modal sosial yang positif dalam 
kehidupan bermasyarakatan, terutama dalam komunitas dengan modal ekonomi yang terbatas, secara konsekuen akan menghasilkan peningkatan kinerja ekonomi dan peningkatan kualitas kehidupan, sedangkan faktor sosial ekonomi menurut penelitian Fikriman (2020) yaitu pendapatan, pendidikan ibu rumah tangga, jumlah anggota keluarga, dan bantuan sosial.

\section{METODEPENELITIAN}

Penelitian ini akan dilaksanakan di Desa Pandan Sejahtera dan Desa Pandan Makmur Kecamatan Geragai, Desa Mencolok Kecamatan Mendahara Ulu dan Desa Rawasari Kecamatan Berbak Kabupaten Tanjung Jabung Timur. Adapun pelaksanaan penelitian ini berlangsung mulai pada 15 bulan Oktober sampai dengan tanggal 30 bulan Desember tahun 2020.

Metode penelitian yang digunakan pada penelitian ini adalah metode survey. Data yang dikumpulkan dalam penelitian ini terbagi dalam 2 sumber, yaitu data primer (pengurus Badan Usaha Milik Desa (BUMDes dan peternak), dan data sekunder dari instansi terkait.

Pada penelitian ini ada 3 tahap teknik penarikan sampel yaitu tahap pertama, penentuan sampel terpilih yaitu memilih sampel mengunakan metode Cluster purposive sampling di Kabupaten Tanjung Jabung Timur,Langkah pertama untuk memperoleh sampel, terlebih dahulu dihitung total ukuran sampel yang akan diambil dari peternak di Desa Pandan Jaya Sejahtera, Desa Pandan Makmur, Desa Mencolok, dan Desa Rawasari yang memiliki BUMDes unit usaha bergerak di bidang peternakan khususnya ternak sapi.

\section{Metode Analisis}

1. Analisis regresi berganda StepWise

$Y=\alpha+\beta_{1} X_{1}+\beta_{2} X_{2}+\beta_{3} X_{3}+\beta_{4} X_{4}+\varepsilon$

Ket:

$\mathrm{Y}$ : Pengembangan BUMDes

$\mathrm{X}_{1}$ : Kepercayaan

$\mathrm{X}_{2}$ : Jaringan Sosial
$\mathrm{X}_{3} \quad$ : Hubungan Timbal Balik

$\mathrm{X}_{4} \quad$ : Norma

$\alpha \quad$ : Koefisien intersep

$\beta 1-4 \quad$ : Koefisien variabel X1 - X4

$\varepsilon \quad$ : Residual atau variabel pengganggu

Sebelum melakukan pengujian hipotesis maka perlu dilakukan uji keseluruhan (over all test) untuk mengetahui pengaruh variabel independen secara bersama-sama terhadap variabel dependen yaitu uji F (F-test). Uji F ini berguna untuk membuktikan secara statistik bahwa keseluruhan koefisien regresi signifikan dalam mempengaruhi nilai variabel dependen. Uji t (t-test) digunakan untuk melihat signifikan pengaruh variabel independen secara individu (parsial) terhadap variabel dependen.

2. Analisis SWOT

Untuk menyusun strategi pengembangan BUMDes Unit Usaha Ternak Sapi di Kabupaten Tanjung Jabung Timur menggunakan analisis SWOT. Dalam analisis SWOT terdiri dari analisis Matriks IFE digunakan untuk mengidentifikasi faktor-faktor lingkungan internal dan menggolongkannya menjadi kekuatan dan kelemahan pengembangan BUMDes unit usaha ternak sapi di Kabupaten Tanjung Jabung Timur melalui pembobotan. Sedangkan, matriks EFE digunakan untuk mengidentifikasi faktorfaktor lingkungan eksternal dan menggolongkannya menjadi peluang dan ancaman pengembangan BUMDes unit usaha ternak sapi di Kabupaten Tanjung Jabung Timur dengan melakukan pembobotan.

\section{Analisis QSPM}

Setelah mengembangkan sejumlah alternatif strategi, BUMDes unit usaha ternak sapi di Kabupaten Tanjung Jabung Timur harus mampu mengevaluasi dan kemudian memilih strategi yang terbaik dan paling cocok dengan kondisi internal serta lingkungan eksternal. 
HASIL DAN PEMBAHASAN

Modal Sosial

Kepercayaan

Berdasarkan hasil survey diatas dapat dilihat bahwa tingkat kepercayaan peternak terhadap orang - orang di Desa cukup tinggi $60 \%$ petenak dikategorikan percaya terhadap masyarakat di Desa, sementara peternak terhadap orang - orang di BUMDes memiliki tingkat kepercayaan sebesar $52 \%$ peternak yang dikategorikan percaya.Hasbullah (2006) berpendapat bahwa rasa percaya (trust) merupakan suatu bentuk keinginan untuk mengambil resiko dalam hubungan sosialnya yang didasari oleh perasaan yakin bahwa yang lain akan melakukan sesuatu seperti yang diharapkan dan senantiasa bertindak dalam suatu pola tindakan saling mendukung.

Temuan lain dapat dilihat bahwa tingkat kepercayaan terhadap penasehat BUMDes sebesar $51 \%$ peternak dikategorikan percaya, untuk tingkat kepercayaan terhadap dewan pengawas BUMDes dan Operasional BUMDes memiliki jumlah $44 \%$ dan $47 \%$ peternak dikategorikan tidak memberikan pendapat dari hasil penelitian ini. Hal ini menunjukan bahwa tingkat kepercayaan peternak terhadap pengembangan BUMDes unit usaha ternak sapi dapat dilakukan di desa yang menjadi objek penelitian ini, sesuai dengan prinsip - prinsip yang ada dalam pengelolaan BUMDes.

Menurut Raisa et al. (2014) kepercayaan merupakan modal yang sangat penting untuk membangun jaringan kemitraan (kerja sama) dengan pihak luar. Kerja sama yang dilandasi kepercayaan akan terjadi apabila dilandasi oleh kejujuran, keadilan, keterbukaan, saling peduli, saling menghargai dan saling menolong diantara anggota kelompok. Pihak luar kelompok seperti koperasi jugaakan memberikan dukungan, bantuan dan kerjasama kepada kelompok apabila kelompok tersebut bisa dipercaya.

\section{Jaringan Sosial}

Hasil penelitian menunjukan jaringan sosial dikategorikan tinggi, kerja sukarela sebanyak $36 \%$ peternak dikategorikan sering, sedangkan mengunjungin orang sakit $45 \%$ peternak dan memberi makanan $40 \%$ peternak tidak memberikan pendapatnya terhadap kuesioner penelitian ini. Untuk memberi tempat tinggal juga peternak berjumlah $29 \%$ orang peternak tidak memberikan pendapat sama dengan pertanyaan ini. Hal ini menunjukan bahwa jaringan sosial di Desa yang memiliki BUMDes unit usaha ternak sapi sangatlah layak untuk dijadikan modal utama dalam pengembangan BUMDes karena ikatan yang kuat antara masyarakat di Desa dikategorikan tinggi. Menurut Kushandajani (2006), jaringan sosial terjadi berkat adanya keterkaitan individu dan komunitas. Keterkaitan terwujud di dalam beragam tipe kelompok pada tingkat lokal maupun di tingkat yang lebih tinggi.

Jaringan sosial merupakan hubungan diantara para pelaku anggota masyarakat atau organisasi sosial. Jaringan sekelompok orang yang dihubungkan oleh perasaan simpati dan kewajiban serta norma pertukaran dan civicengagement. Jaringan ini bisa dibentuk karena berasal dari daerah yang sama,kesamaan kepercayaan politik atau agama, hubungan geneologis dan lainlain. Jaringan sosial tersebut diorganisasikan menjadi sebuah institusional yang memberikan perlakuan khusus terhadapmereka yang dibentuk oleh jaringan untuk mendapatkan modal sosial dari jaringan tersebut (Samsul et al., 2015).

Menurut Mirajiani et al., (2014) jaringan sosial terbentuk karena adanya kesamaan dalam produksi dan distribusi sumberdaya yang menyebabkan adanya pihak yang memiliki kekuasaan atau kemampuan untuk mengontrol sumberdaya dan adanya pihak yang dikontrol. Menurut Agusyanto (2007), jaringan sosial merupakan suatu jaringan tipe khusus dimana "ikatan" yang menghubungkan satu titik ke titik lain di dalamnya ialah hubungan sosial. Dalam hal ini, hubungan 
sosial diikat oleh adanya unsur kepercayaan yang mana kepercayaan itu dipertahankan oleh adanya norma-norma yang ada.

\section{Hubungan Timbal Balik}

Hubungan sosial di Desa yang memiliki BUMDes unit usaha ternak sapi dikategorikan cukup tinggi karna didalam kuesioner penelitian ini ditunjukan bahwa kehidupan di Desa masih saling membantu dalam hal kegiatan sosial seperti bilang terjadi musibah dan acara $32 \%$ orang peternak menyatakan selalu saling membantu, sementara untuk dalam hal keagamaan seperti terjadinya acara tahlilan, yasinan, maulid nabi dan lain - lain $48 \%$ orang peternak siap saling membantu dengan yang lainnya. Sedangkan saling membantu dalam hal usaha tani $44 \%$ peternak memilih tidak memberikan pendapat dalam kuesinior penelitian ini dan untuk kegiatan ekonomi lain seperti BUMDes $64 \%$ peternak juga memilih tidak ada pendapat tentang kegiataan ekonomi yang berada dalam Desa yang memiliki BUMDes unit usaha ternak sapi, akan tetapi peternak tetap ada rasa kebersamaan yang tinggi walaupun dalam kuesioner penelitian ini peternak lebih memilih tidak menyampaikan pendapatnya.

Modal sosial selalu diwarnai oleh kecenderungan saling bertukar kebaikan diantara individu-individu yang menjadi bagian atau anggota jaringan. Hubungan timbal balik ini juga dapat diasumsikan sebagai saling melengkapi dan saling mendukung satu sama lain (Hasbullah, 2006). Modal sosial selalu bercirikan saling tukar kebaikan (resprocity) antar individu dalam suatu kelompok ataupun antar kelompok dalam suatu masyarakat (Hasbullah, 2006). Soetomo (2006) reciprocity (hubungan timbal balik) yang merupakan tindakan bersama yang ditunjukkan dengan saling memberi respon. Reciprocity dapat dijumpai dalam bentuk memberi, saling menerima, saling membantu, yang dapat muncul dari interaksi sosial

\section{Norma}

Modal sosial tentang norma dapat disimpulkan bahwa tidak ada norma khusus dalam menjalankan kehidupan sosial bermasyarakat dan dalam aturan BUMDes pun sama halnya tidak ada juga peraturan yang lain selain aturan dalam surat keputusan tentang BUMDes yang telah disahkan. Menurut Fukuyama (2000) norma adalah sekumpulan aturan yang diharapkankan, dipatuhi dan diikuti oleh anggota masyarakat pada suatu kehidupan sosial tertentu.

Norma sosial merupakan sekumpulan aturan yang diharapkan, dipatuhi dan diikuti oleh masyarakat dalam suatu entitas tertentu. Aturan-aturan ini biasanya terinstitusionalisasi, tidak tertulis tapi dipahami sebagai penentu polah tingkah laku yang baik dalam kontek hubungan sosial sehingga ada sanksi sosial yang diberikan jika melanggar. Normal sosial akan menentukan kuatnya hubungan antar individu karena merangsang kohesifitas sosial yang berdampak positif bagi perkembangan masyarakat. Oleh karena norma sosial disebut sebagai salah satu modal sosial (Inayah, 2012).

\section{Pengaruh Modal Sosial}

Pengaruh modal sosial terhadap pengembangan Badan Usaha Milik Desa (BUMDes) unit usaha ternak sapi di Kabupaten Tanjung Jabung Timur digunakan analisis Regresi Berganda StepWise. Persamaan regresi yang dihasilkan mempunyai nilai R-Square sebesar 0,292 artinya 29,20 \% pengembangan BUMDes Unit usaha ternak sapi di Kabupaten Tanjung Jabung Timur data dapat dijelaskan oleh variabel dalam model regresi yaitu variabel Kepercayaan $\left(\mathrm{X}_{1}\right)$, Jaringan Sosial $\left(\mathrm{X}_{2}\right)$, Hubungan Timbal Balik $\left(\mathrm{X}_{3}\right)$, dan Norma $\left(\mathrm{X}_{4}\right)$, sedangkan sisanya sebesar $70,80 \%$ pengembangan BUMDes unit usaha ternak sapi di Kabupaten Tanjung Jabung Timur dijelaskan oleh variabel lainnya yang tidak masuk ke dalam model penelitian ini. 
Hasil analisis uji $\mathrm{F}$ diperoleh nilai Fhitung $=20,2513$ dengan significant $=$ 0,000 yang berarti hipotesis nol ditolak dan hipotesis alternatif diterima, artinya sekurang-kurangnya terdapat satu nilai koefisien yang berarti (signifikan). Hasil ini menunjukkan bahwa variabel Kepercayaan $\left(\mathrm{X}_{1}\right)$, Jaringan Sosial $\left(\mathrm{X}_{2}\right)$, Hubungan Timbal Balik $\left(\mathrm{X}_{3}\right)$, dan Norma $\left(\mathrm{X}_{4}\right)$ secara simultan mempengaruhi pengembangan BUMDes unit usaha ternak sapi di Kabupaten Tanjung Jabung Timur. Oleh karena hasil pengujian secara simultan (uji F) adalah signifikan, maka selanjutnya dilakukan pengujian secara parsial (uji t). Uji t dilakukan untuk melihat secara parsial pengaruh variabel Kepercayaan $\left(\mathrm{X}_{1}\right)$, Jaringan Sosial $\left(\mathrm{X}_{2}\right)$, Hubungan Timbal Balik $\left(\mathrm{X}_{3}\right)$, dan Norma $\left(\mathrm{X}_{4}\right)$ terhadap pengembangan BUMDes unit usaha ternak sapi di Kabupaten Tanjung Jabung Timur. Berdasarkan uji $\mathrm{t}$ diperoleh dua variabel independen yang tidak signifikan yaitu variabel Hubungan Timbal Balik $\left(\mathrm{X}_{3}\right)$ dan Norma $\left(\mathrm{X}_{4}\right)$, sedangkan dua variabel independen yang lain yaitu variabel Kepercayaan $\left(\mathrm{X}_{1}\right)$ dan Jaringan Sosial $\left(\mathrm{X}_{2}\right)$ adalah signifikan.

Persamaan regresi yang dihasilkan mempunyai nilai R-Square sebesar 0,276 artinya $27,60 \%$ pengembangan BUMDes unit usaha ternak sapi di Kabupaten Tanjung Jabung Timur data dapat dijelaskan oleh variabel dalam model regresi yaitu variabel Kepercayaan $\left(\mathrm{X}_{1}\right)$ dan Jaringan Sosial $\left(\mathrm{X}_{2}\right)$, sedangkan sisanya sebesar 72,40 \% pengembangan BUMDes unit usaha ternak sapi di Kabupaten Tanjung Jabung Timur dijelaskan oleh variabel lainnya yang tidak masuk ke dalam model penelitian ini.

Uji F dilakukan untuk melihat secara simultan pengaruh variabel Kepercayaan $\left(\mathrm{X}_{1}\right)$ dan Jaringan Sosial $\left(\mathrm{X}_{2}\right)$ terhadap pengembangan BUMDes unit usaha ternak sapi di Kabupaten Tanjung Jabung Timur. Hasil analisis uji $\mathrm{F}$ diperoleh nilai Fhitung $=37,796$ dengan significant $=0,000$ yang berarti hipotesis nol ditolak dan hipotesis alternatif diterima, artinya sekurang- kurangnya terdapat satu nilai koefisien yang berarti (signifikan). Hasil ini menunjukkan bahwa variabel Kepercayaan $\left(\mathrm{X}_{1}\right)$ dan Jaringan Sosial $\left(\mathrm{X}_{2}\right)$, secara simultan mempengaruhi pengembangan BUMDes unit usaha ternak sapi di Kabupaten Tanjung Jabung Timur. Oleh karena hasil pengujian secara simultan (uji F) adalah signifikan, maka selanjutnya dilakukan pengujian secara parsial (uji t). Uji t dilakukan untuk melihat secara parsial pengaruh variabel Kepercayaan $\left(\mathrm{X}_{1}\right)$ dan Jaringan Sosial $\left(\mathrm{X}_{2}\right)$ terhadap pengembangan (BUMDes) unit usaha ternak sapi di Kabupaten Tanjung Jabung Timur. Berdasarkan uji t diperoleh variabel Kepercayaan $\left(\mathrm{X}_{1}\right)$ dan Jaringan Sosial $\left(\mathrm{X}_{2}\right)$ adalah signifikan.

$\begin{array}{ccc}\begin{array}{c}\text { Kepercayaan } \\ \text { berpengaruh }\end{array} & \text { secara } & \text { parsial } \\ \text { positif } & \text { terhadap }\end{array}$ pengembangan (BUMDes) unit usaha ternak sapi di Kabupaten Tanjung Semakin tinggi kepercayaan peternak terhadap pengurus BUMDes, maka semakin berkembang BUMDes unit usaha ternak sapi di Kabupaten Tanjung Timur. Unsur terpenting dalam modal sosial adalah kepercayaan (trust) yang merupakan perekat bagi langgengnya kerjasama dalam kelompok peternak. Menurut Indra (2008), dengan kepercayaan (trust), orang-orang akan bisa bekerjasama secara lebih efektif.

Menurut Mawardi (2007) modal sosial tidak dibangun hanya oleh satu individu, melainkan terletak pada kecenderungan yang tumbuh dalam suatu kelompok untuk bersosialisasi sebagai bagian penting dari nilai-nilai yang melekat.Jaringan sosial secara parsial berpengaruh positif terhadap pengembangan BUMDes unit usaha ternak sapi di Kabupaten Tanjung Jabung Timur. Semakin tinggi jaringan social peternak terhadap pengurus BUMDes, maka semakin berkembang BUMDes unit usaha ternak sapi di Kabupaten Tanjung Jabung Timur. 
Strategi Pengembangan BUMDes

Analisis SWOT terdiri dari analisis Matriks IFE digunakan untuk mengidentifikasi faktor-faktor lingkungan internal dan menggolongkannya menjadi kekuatan dan kelemahan pengembangan BUMDes unit usaha ternak sapi di Kabupaten Tanjung Jabung Timur melalui pembobotan :

a. Faktor Kekuatan (Strengths) dalam pengembangan BUMDes unit usaha ternak sapi di Kabupaten Tanjung Jabung Timur adalah dukungan kebijakan pemerintah melalui dana desa dalam bentuk APB desa dan pendamping desa, sumberdaya alam khususnya pakan yang mendukung pengembangan ternak, peternak yang berpengalaman, dan modal sosial peternak yang tinggi.

b. Faktor Kelemahan (Weaknesses) dalam pengembangan BUMDes unit usaha ternak sapi di Kabupaten Tanjung Jabung Timur adalah struktur organisasi BUMDes yang tidak efisiensi, kualitas sumberdaya manusia pelaksana operasional yang masih rendah, modal kerja yang terbatas, dan pola pembagian hasil usaha yang belum optimal.

Sedangkan, matriks EFE digunakan untuk mengidentifikasi faktor-faktor lingkungan eksternal dan menggolongkannya menjadi peluang dan ancaman pengembangan BUMDes unit usaha ternak sapi di Kabupaten Tanjung Jabung Timur dengan melakukan pembobotan :

a. Faktor Peluang (Oppurtunities) dalam pengembangan BUMDes unit usaha ternak sapi di Kabupaten Tanjung Jabung Timur adalah harga produk ternak yang mahal, tingkat permintaan produk ternak yang tinggi, jaringan BUMDes bersama, kerjasama kemitraan dengan berbagai pihak.

b. Faktor Ancaman (Threats) dalam pengembangan BUMDes unit usaha ternak sapi di Kabupaten Tanjung Jabung Timur adalah banyak pesaing
BUMDes sejenis, regulasi pemerintah yang berubah-ubah

\section{Analisis QSPM}

Setelah mengembangkan sejumlah alternatif strategi, BUMDes Unit usaha ternak sapi di Kabupaten Tanjung Jabung Timur harus mampu mengevaluasi dan kemudian memilih strategi yang terbaik dan paling cocok dengan kondisi internal serta lingkungan eksternal berdasarkan Analisis QSPM (Quantitative Strategic Planning Matriks) yaitu Penguatan kapasitas modal sosial terutama kepercayaan dan jaringan untuk pengembangan BUMDes unit usaha ternak sapi di Kabupaten Tanjung Jabung Timur melalui pemeliharaan kearifan lokal (local wisdom) yang mempunyai makna bahwa struktur sosial peternak masih mengandung sifat arif yaitu nilai-nilai sosial yang digunakan sebagai sumber pemikiran dan pedoman berperilaku anggota dan pengurus BUMDes. Peningkatan kepercayaan peternak terhadap BUMDes melalui pengelolaan BUMDes yang transparan, akuntabel, dan berlandaskan nilai-nilai kejujuran.

\section{KESIMPULAN}

Berdasarkan hasil penelitian dapat disimpulkan sebagai berikut:

1. Pengembangan BUMDes unit usaha ternak sapi di Kabupaten Tanjung Jabung Timur dipengaruhi oleh modal sosial berupa kepercayaan dan jaringan sosial,

2. Strategi pengembangan BUMDes unit usaha ternak sapi di Kabupaten Tanjung Jabung Timur adalah penguatan kapasitas modal sosial dengan peningkatan kepercayaan peternak pengelolaan BUMDes yang transparan, akuntabel, dan berlandaskan nilai-nilai kejujuran.

\section{Daftar Pustaka}

Agusyanto, R. (2007). Jaringan social dalam organisasi. Jakarta: PT Raja Grafindo Persada. 
Arbi, J. S. L., Manse, M. A. V., Lumenta, L. R. D., dan Rundengan, M. L. (2016). Analisis Usaha Kelompok Tani Ternak Sapi "Pelita" Di Desa Tonsewer Kecamatan Tompaso Barat Kabupaten Minahasa. Jurnal Zootek, 36(1), 207-217.

Carpenter, J.P, et al. 2004. Social Capital and Trust in South-east Asian Cities, Urban Studies 41 (4), 853-874.

Departemen Pendidikan Nasional Pusat Kajian Dinamika Sistem Pembangunan (PKDSP). 2007. Buku Panduan Pendirian dan Pengelolaan Badan Usaha Milik Desa (BUMDes). Fakultas Ekonomi: Universitas Brawijaya. Malang.

Fikriman, F., Budiman, F. A., \& Afrianto, E. (2020). Faktor Sosial Ekonomi yang Mempengaruhi Pengeluaran Pangan Rumah Tangga Miskin di Kecamatan Bangko Kabupaten Merangin. JAS (Jurnal Agri Sains), 4(2), 149-161.

Fukuyama, F. (1995) Trust: The Social Virtues and Creation of Prosperity. New York: Free Press Paperbacks.

Hasbullah. 2006. Sosial Kapital : Menuju Keunggulan Budaya Manusia Indonesia.MR-United Prees, Jakarta.

Inayah. 2012. Peranan Modal Sosial dalam Pembangunan. Ragam: Jurnal
Pengembangan Humaniora Politeknik Negeri Semarang Vol. 12 No.1.

Indra. 2008. Pemetaan dan Pemanfaatan Modal Sosial dalam Penanggulangan Kemiskinan di Jawa Barat. 2010.pdf. diakses pada tanggal 20 Februari 2018.

Kushandajani. 2006. Strategi Penguatan Modal Sosial Melalui Pendidikan (Belajar Dari Masyarakat Desa). Prosiding. Universitas Diponegoro, Semarang.

Mawardi M. 2007. Peranan Sosial Capital dalam Pemberdayaan Masyarakat. Komunitas Jurnal Pengembangan Masyarakat Islam, Volume 3 Nomor 2.

Putra. K. 2008. Modal Sosial dan Pemberdayaan Desa Prakraman (Studi Kasus Pengelolaan LPD Desa Prakraman Batuaja Kawan, Kabupaten Tabana, Provinsi Bali). (Tesis). Sekolah Pascasarjana, Yogyakarta: Universitas Gajah Mada. Soetomo. 2006, Masalah Sosial dan Upaya Pemecahannya, Jakarta: Bumi Aksara.

Siregar, G. 2012. Analisis Kelayakan Dan Strategi Pengembangan Usaha Ternak Sapi Potong. 17(3), 192-201. 